\title{
Research of the collapsibility of the European loess - review
}

\author{
Agnieszka Lal \\ Department of Geotechnical Engineering, Faculty of Civil Engineering and Architecture, \\ Lublin University of Technology, e-mail: a.lal@pollub.pl, ORCID: 0000-0002-3557-6064
}

\begin{abstract}
Foundation of the buildings on the loessial soil is often associated only with difficulties resulting from the possibility of the collapse of the ground. For these reason, loess is too often unfairly disqualified as the construction subsoil in spite of its good strength and strain parameters. Thanks to continuous development of research and publications of the results, reliable data regarding loess are spread and, as a consequence, loess becomes more and more common soil used in the geotechnical engineering.

Loess collapsibility has been studied since the middle of the 20th century, nevertheless, only the computer techniques and specialist laboratory and microstructural tests, that have been developed from the end of last century, helped us to find an answer to the important questions regarding the occurrence of this phenomenon. Detailed mechanisms that cause sudden loess volumetric reduction due to humidity and load, and the elements that affects the collapsibility are still studied. Furthermore, varied technics are researched, including in-situ tests, which allow estimating the risk of collapse, as well as the methods of its elimination.

The aim of this paper is to systematize the directions of current studies of European loess collapsibility and to indicate their most significant results. The review was made on the basis of the scientific publications published in the Polish and international journals as well as the Journal Citation Reports (JCR) Web of Science database.
\end{abstract}

Keywords: loess, collapsibility, soil structure, in-situ test, laboratory test

\section{Introduction}

Loessial soil occurs in many areas, in each of them being soils of special importance. Because of their unique properties, they constitute an important domain of global research in various branches of science. Paleopedology, geomorphology, geology, as well as geotechnics are the examples of fields, where the research on the subject of the loess is still not exhausted. In spite of the intensive development of this scientific domain, the majority of easily accessible papers do not discuss the subject of the loess profoundly enough.

The genesis of the loess has been widely discussed over the past few decades in the circles of notable geologists around the world [1]-[6]. It aroused disagreements among supporters of various monogenetic concepts [7]-[17], until in the sixties and seventies of the twentieth century, the research, which was an attempt to reconstruct the conditions for the accumulation of the loessial soils, allowed to confirm the polygenetic concept [18]. The complexity of processes, which affect the shaping of these soils, makes it very difficult to define them unequivocally. The principle of granulometric composition, frequently used because of its simplicity, results in the erroneous inclusion in the definition of „loess" the soils with a completely different origin. In the cited monographs [19]-[22], the authors presented 
a consistent view on the need to classify loess on the basis of the origin of the soil. One of the most accurate is the definition of the loess as a Pleistocene extraglacial work, which was transported and sedimentated in the syngenetic stage mainly via the aeolian pathway.

The specific genesis of the loess, affecting the size, shape and arrangement of its particles, as well as the mineralogical composition translate into its well-known sensitivity to water. The rapid changes in volume observed in a part of soils of this type, which are the result of dampness and even a small load, were called the collapse subsidence and were mentioned as the one of the main properties, which, next to the adoption of appropriate geotechnical parameters, should be taken into account when designing foundation structures on the loess soil. It is known, however, that the collapsibility does not apply to all loess [23], [24]. Meanwhile, even in the areas where its occurrence is very common, loess is often disqualified as a stable substrate that can be used for foundation designed for various buildings, only because of the possible collapsibility. Laboratory and field tests indicate, in many cases, good and very good strength and strain parameters of loess [25], [26]; therefore, omitting it when choosing a foundation may result in the adoption of uneconomi-cal construction solutions. Only after supplementary research it is possible to determine the risk of collapsibility in the given area. The results of laboratory and field tests provide the basis for reliable static and strength analysis of the setting. Determining of the sensitivity of the loess to water does not, however, compromise its suitability for the foundation of a building, but indicates the need for dewatering in the immediate vicinity of a designed foundation. If the preventive measures are undertaken and the entry of technological or atmospheric water to the foundation level is forefended, the risk of collapsibility will be eliminated, which will allow full construction use of the loessial substrate. It is important to recognize the loessial soil at the place of the investment both in terms of its geotechnical parameters and sensitivity to water, and then to conduct a thorough analysis of the obtained results.

Scientific research enables to increasingly better understand the mechanism and causes of collapsibility, and papers presenting extensive analyses of this phenomenon spread reliable information. Thanks to this, engineers and geologists have more and more knowledge of the loess behaviour. This paper presents the main directions of research on European loess collapsibility. The analysis of scientific publications was carried out on the basis of national and international journals from the Journal of Citation Reports (JCR) database of the Web of Science.

\section{Research of collapsibility of European loess}

There are various directions adopted by the authors of the scientific papers devoted to the collapsibility of the European loess. One of them is the study of the loess microstruc-ture, which is sought to be the cause of sensitivity to water. The scanning electron micro-scope SEM is widely used in this type of research. In case of a set of works dedicated to find the influence of the loess microstructure on the water retention curve and changes in the volume of loess due to changes in humidity, the SEM test served to confirm the theses along with the mercury intrusion porosimetry test carried out in parallel [27]. The authors of the paper have identified a range of stress in which intact loess and reconsolidated loess show a greater hysteresis of the water retention curve. On the basis of the conducted tests, hysteresis was found in the entire examined stress range, i.e. $0-400 \mathrm{kPa}$ and 4-140 MPa, however, to the level of stress of $20 \mathrm{kPa}$ it was more pronounced for loess of an intact structure, and in the case of the levels of stress exceeding $30 \mathrm{kPa}$ - more significant for reconsolidated loess (Fig. 1). 

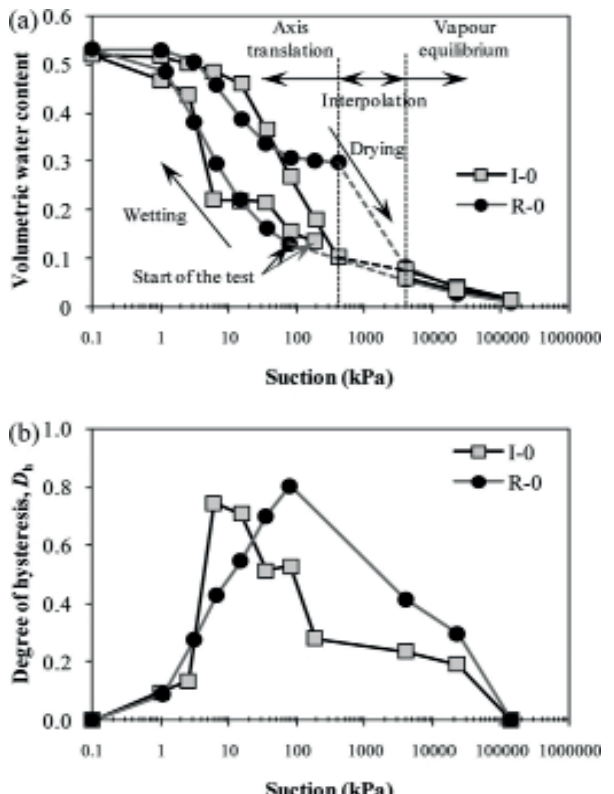

Fig. 1 Comparison of water retention curves (a) and hysteresis level (b) for intact loess and reconsolidated loess.

As a result of the study, the authors created a conceptual model combining the water retention curve with the corresponding function of the density and pore size of the loessial soil.

Loughborough University, where English engineers have identified geometric models of four types of pores, six main types of structures and three processes related to the loess collapsibility [32]. The results of computer-generated geometry models were correlated by the authors with the results of oedometer tests carried out on loess samples reproduced under laboratory conditions. It was found that laboratory soil samples (prepared on the basis of accepted accumulation techniques) correspond to the obtained geometric models and, more importantly, to the natural loess. Moreover, based on the computer-generated geometric model of loess accumulation, it was observed that the pores resulting from the random collapse of model particles often gain a vertical shape, reaching even $80 \%$ of the sample height. It is emphasized that it is possible that this type of pores, typical for loess, occurs as a result of genetic processes, and not vegetation, as commonly believed.

The procedure of the preparation of loess samples under laboratory conditions was also developed by Arya Assadi Langroudi [33]. In his work, the author included information on current knowledge regarding collapse subsidence and methods applied to prevent it. In his considerations, he raised the issue of micromechanisms causing rapid change in the volume of soil under the action of water and load, and optimization of practices to strengthen this type of ground. The research was carried out on samples of loess prepared under laboratory conditions, according to a strictly established procedure, specific granulometric composition and percentage of minerals (kaolinite and carbonates). Due to this approach, tested soil samples were identical, and the determined strength of dust particles, dust bonds and intermolecular forces in different humidity and stress conditions were meaningful. In his paper, the author separated 11 major types and 40 subtypes of loess, for which he determined the risk of collapsibility, and using the edometric test he verified the effectiveness of the loess 
consolidation with the use of selected methods.

Arya Assadi Langroudi and Ian Jefferson [34] point out in their paper regarding loess subjected to water, stress and drying due to the exploitation of a building that the geological past of the loess (in terms of its humidity and loads acting on it) has a great influence on the arrangement of particles. The considerations were carried out on the basis of the results of the research concerning microstructure, particle size and arrangement, as well as loess pores subjected to gradual load increase. Tested samples were prepared in a laboratory according to the procedure which facilitated obtaining uniform samples, some of which were subjected to a selected stress pathway in the dry state, some in the humid state, and the rest in the saturated state. Based on the results of the research, conclusions have been drawn regarding dampness of the loess samples under any load, as a factor affecting the reduction of collapsibility after drying. Initial stress of $25 \mathrm{kPa}$ prior to hydration of the sample was considered to be the cause of the largest increase in its density. At the same time, the content of particles with dimensions of 5-20 $\mu \mathrm{m}$ was assessed as defining the permanent retention properties of the loess after the cycle of its watering and drying. As a result of the conducted research, the authors found the possibility of strengthening loess hydrotechnical buildings with a controlled cycle of loading and watering.

Apart from the microstructure and external factors, the behaviour of the loess is also determined by its physical properties, mainly related to the natural moisture of the soil residing in the substrate and its porosity. The studies of the impact of these properties on collapsibility were carried out on loess samples in a direct shear apparatus [35]. It should be emphasized that the tests were carried out both on samples characterized with natural moisture, and after their full saturation with water. As a result of the research, the conclusion was drawn that the humidity and porosity are the main factors determining the structure of the soil in terms of its susceptibility to moisture. Moreover, it was found that these factors manifest themselves simultaneously and are interdependent.

The results of the oedometer tests of samples of Belgrade loess of intact structure taken from exploratory boreholes were compared with the results of parallel in-situ tests using a dilatometer (SDMT) [36]. Obtained sizes of edometric module Eoed for samples characterized with natural humidity were found to be highly consistent with the values of MDMT modules from the in-situ test. On the basis of the performed studies, two possible methods of defining the collapse potential of the loess were determined with the use of the results of the dilatometric test. One of them consists in determination of the ratio of the strain modulus to the edometry module G0/MDMT and its interpretation, the second one the indication and interpretation of intermediate parameters, such as ID and KD. Clear and coherent conclusions allow us to attempt to apply the criteria of collapsibility indicated in Serbia for the loess from other areas.

Serb loess was also subjected to oedometric test regarding the collapsibility. Meanwhile, observations of subsidence of the existing complex of agricultural buildings were performed [37]. The complex located near Feketić included a mill, an outhouse and an accompanying grain silos. Due to the temporary storage of grains, the stresses transmitted to the loess bed were variable over time, with the maximum stress level of $190 \mathrm{kPa}$ for the silo (including $48 \%$ of its own weight) and $155 \mathrm{kPa}$ (59\% of its own weight) for the mill. In order to identify the ground, 8 test drillings to a depth of $14.0 \mathrm{~m}$ and two cone penetration tests CPT were made. The samples of an intact structure from a test excavation and from the depth with a use of a thin-walled Shelby tube were taken for the laboratory tests. Field and laboratory tests allowed the determination of the geotechnical conditions occurring in the ground. The 
dominant substrate was loess with a thickness of about $12 \mathrm{~m}$, occurring directly above the layer of fine-grained medium-thickened and compacted sands. A double oedometer test helped to qualify the loess as unquestionably collapsible. Subsidence calculations were made for loess with natural dampness, which was assumed, because it was obviously not possible to allow the ground to get moist or to allow water to infiltrate the level of foundation. The calculations were made using the numerical method (elastic foundation) using strain parameters, loads and the foundation level, obtaining the result of $136 \mathrm{~mm}$ of subsidence for the silo and 97 $\mathrm{mm}$ for the mill. Based on geodetic measurements conducted with the installed points of the geodetic network with an accuracy up to $0.5 \mathrm{~mm}$, it was found that the real subsidence of the mill reached the value of $109 \pm 33 \mathrm{~mm}$, and the silo $-175 \pm 38 \mathrm{~mm}$. Actual subsidence was measured over 45 months. On the basis of precise analysis, it was found that the difference between the calculated and actual subsidence values resulted from the partial collapsibility, which the ground underwent due to increased precipitation and infiltration of rainwater, with the simultaneous exposure to a significant load. Due to the lack of relevant tests, the increase of the dampness content in the loess forming the ground was estimated on the basis of the amount of rainfall, the filtration factor of the soil and its retention properties. Renewed numerical analyses made for a group of buildings, taking into account the moisture of the ground, allowed the determination of a potential subsidence of $183 \mathrm{~mm}$. The obtained result was classified as large, but not excluding future safe use of the facilities provided that specific recommendations on geodetic control measurements are observed and the drainage in the foundation level is improved.

The in-situ and laboratory tests were also conducted in southern England (near Kent) in order to determine the loess' collapsibility. The scope of field tests included testing the collapsibility on a large-size soil sample treated with water until full saturation and then surface-loaded (with the stress of $210 \mathrm{kPa}$ ) for a period of 10 days. Weakening of intermolecular forces during subsidence was documented with the use of various geophysical and geotechnical instruments. The field test of the collapsibility eliminates the problems related to the intake of the intact soil sample and a small scale of the study. The results of laboratory tests (edometric determining of collapsibility) and in-situ tests were matched in order to compare the soil behaviour under the same load, but under two different test conditions [38].

The oedometer tests were also used by Hungarian researchers to determine the collapsibility of the loess [39]. Several dozen performed tests allowed the determination of the dependence of rapid subsidence on the natural humidity of the soil. In the subsidence curves, which present the results of the tests, 3 zones were separated - before a sudden change of the height of the test sample, during collapse subsidence, and after its completion (Figure 2). 


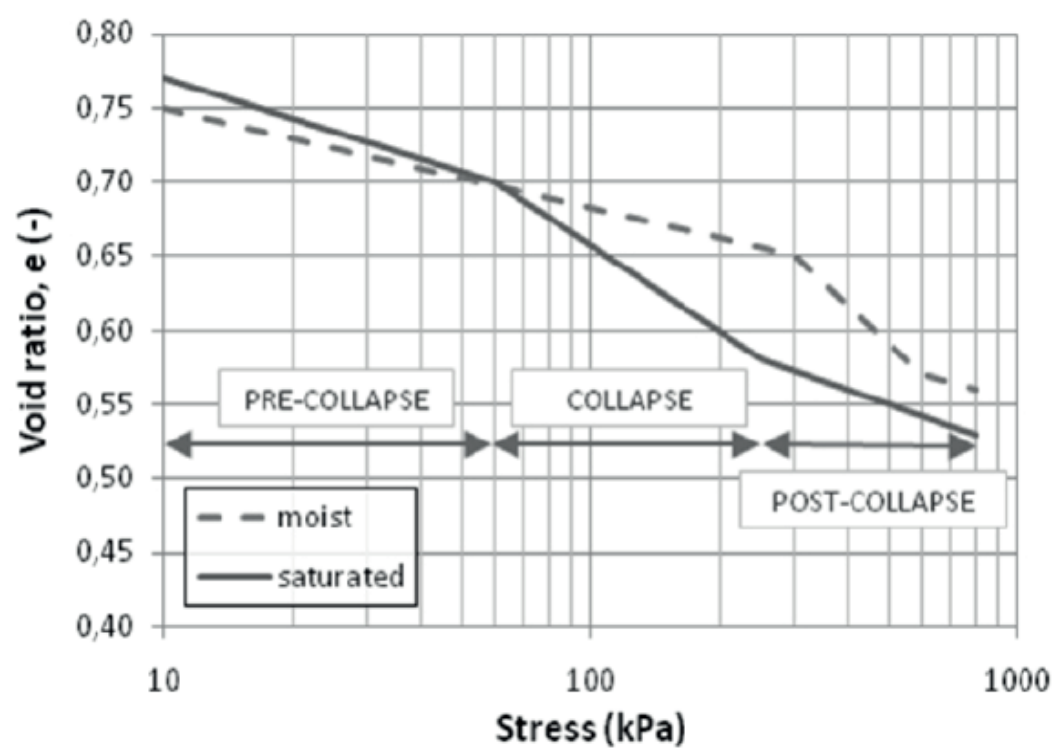

Fig. 2 Typical result of an oedometer test.

Moreover, it was found that in case of soil samples with higher natural humidity, water saturation at higher stress values results in less collapsibility.

Another aspect of the collapsibility of loess was covered by Bulgarian and English researchers: namely, the impact of subsidence on construction, on the example of loess in Western Europe, particularly in Bulgaria [40]. In their work, they focused on estimating the effectiveness of strengthening the loess soil, on the example of the methods used in Bulgaria. In order to determine the safest and most economical solutions applied, the works were undertaken aiming at the analysis of the foundations designs on loessial soil, measurement of the change in soil volume, and determination of the effectiveness of the applied reinforcement method on the basis of the results of tests conducted after reinforcement.

The effectiveness of reinforcement of the substrate with the use of a chosen method was also studied by Alan Lutenegger, Ph.D. [41]. The analysis was carried out with in-situ tests (dynamic probe and dilatometer) and laboratory density tests, determining the loessial soil before and after applying the dynamic load. The load was applied by dropping a concrete compactor of 15 tons from a height of 5-10 m from the surface. As a result of the conducted research, the influence of dynamic loess substrate density on the potential collapsibility was also determined. Similar research was carried out in Romania to indicate the effectiveness of reinforcement of the loessial soil using the dynamic method [42] and estimating the range of the active zone of the surface load [43]. Estimation of the active zone was associated both with the observation of real structures, mounted on the loess ground and with detailed laboratory tests with the use of an oedometer and a triaxial apparatus.

In the considerations regarding the reinforcement of the loess substrate, one cannot omit the work of the geologist Evstatiev, who describes eight types of techniques tested on loess soils from many areas [44]. There are two main types and four subclasses of the loess depending on their thickness and on the demonstrated collapsibility. Reinforcement 
techniques can be divided into densification (in a dynamic way, by dampness, vibrations, etc.), change in granulometric composition by adding thicker fractions, surface or volume stabilization with chemical additives or binders, with the use of jet grouting, introduction of elements resistant to stretching into loess, geomembranes, particle drying (electroosmosis, drainage or hygroscopic materials), and finally appropriate shaping of the loess slopes.

A new method of reinforcement of loess with the use of nano-particles of clay was examined by an international group of scientists [45]. Laboratory and in-situ tests were carried out on loess on which the dam in Gonbad in Iran is built. The nano-particles of clay were added to the representative samples of loess in weight proportion ranging from $0.2 \%$ $3 \%$. For such prepared samples, Atteberg's boundaries were determined, as well as Proctor density, compressive strength, collapsibility, and a triaxial compression test was performed without runoff. Moreover, field tests have been carried out in a dedicated research area of loess modified with nano-particles of clay. As a result of the conducted tests, it was found that the addition of nano-particles impacts the change of plasticity, compressive strength, stiffness and collapsibility of loess. The results of laboratory and field tests were considered to be convergent, and the addition of nano-clay particles in the proportion of $2 \%$ to the weight of the loess was assessed as the cause of its distinct reinforcement.

The analysis of the change of the plasticity level as a result of many years of floods was conducted in the loess areas in the Volga basin in the European part of Russia [46]. The mentioned paper describes the loess dust in terms of its geotechnical properties, as well as its geological origin. Significant deterioration of the state of the soil was determined, which due to the action of the long-term increased water level changed its consistency from compact to plastic.

Despite the risk due to collapsibility of loess, which is described, among others, on the example of the loess areas of Hungary [47] or Moldova [48], these substrates are often used for construction. The reason of this is mainly that for the most part they occur in a compact, semi-dense or hardplastic consistency, and that is why they have good strength and strain characteristics [26].

\section{Summary}

The analysis of the papers regarding the subject of collapsibility allows us to ascertain that studies of European loess collapsibility are conducted in many various ways. This extremely important feature is determined with various methods, using both in-situ, laboratory and computer tests. There are many threads mentioned in the papers, which are known to geotechnics for decades, as well as completely innovative approaches to this topic.

The leading examples of research trends regarding European loess collapsibility are the analysis of microstructure, studies of external factors affecting the soil, physical aspects, such as two main characteristics of the loess - porosity and natural humidity, analysis of applied methods of reinforcement of collapsible grounds and the study of the possibility of applying in-situ tests to determine the collapse potential of the loess.

It's important to develop continuously the research and further enlarge of the data set, which in the future may help us to use the existing knowledge to create new standards and guidelines facilitating the research and design process for buildings located on subsidence substrates. The analysis presented in this paper was mainly based on international papers published in the Journal of Citation Reports (JCR) list of the Web of Science database. It means that it's possible and even certain that the important results of local tests regarding 
loess collapsibility are still not reported to the international news. Therefore, it is necessary to update the global state of knowledge on this subject.

\section{References}

[1] Tungsheng L., Loess and the Environment, Beijing: China Ocean Press, p. 1-481, 1985.

[2] Dylik J., Zagadnienie genezy lessu w Polsce, Biuletyn Peryglacjalny, vol. 1, p. 19-30, 125-131, 1954.

[3] Smalley I. J., „In-situ” theories of loess formation and the significance of the calcium-carbonate content of loess, Earth Science Reviews, vol. 7, no. 2, p. 67-85, 1971. DOI:10.1016/00128252(71)90082-1

[4] Pye K., Aeolian dust and dust deposits. 1987.

[5] Grabowska-Olszewska B., Wiązania strukturalne w lessach i ich wpływ na osiadanie zapadowe, p. 65-69.

[6] Jahn A., Less , jego pochodzenie i związek z klimatem epoki lodowej, vol. 1, 1919.

[7] Kriger N. J., Less, jego swojstwa i swiaz’ s gieograficzieskoj sriedoj. 1965.

[8] Różycki S. Z., Pyłowe utwory typu lessowego na świecie ich występowanie i geneza, Studia Geol. Polonica, vol. LXXXV, p. 193, 1986.

[9] Lysenko M., V. V. Dokuchayev i lessovaya problema, Pochvovedemye, vol. 7, p. 59-67, 1956.

[10] Obruchev V. $\Lambda$., Loess as a particular kind of soil, its genesis and the tasks of its investigation, Byulleten' Kommissii po Izucfteniyit Chetverlichnogo Periods, vol. 12, p. 5-17, 1948.

[11] Łoziński W., „Die periglaziale Fazics der mechanischen Verwitterung”, [in:] Compte Rendu de la XI :e Session du Congrès Géologique Internationale, 1912, p. 1039-1053.

[12] Geikie J., The tundras and steppes of prehistoric Europe, Scottish Geographical Magazine, vol. 14, no. 6, p. 281-294, 1898.

[13] Berg L. S., Loess as a product of weathering and soil formation. 1960.

[14] Gansen R., Die Entstehung und Herkunft des Löss. 1922.

[15] Richthofen F., China. 1877.

[16] Hoobs W. H., The glacial anticyclones and the European continental glacier, American Journal of Science, vol. 241, no. 4, p. 333-336, 1943.

[17] Soergel W., Lösse, Eiszeiten und paläolitische Kulturen. 1919.

[18] Maruszczak H., Definicja i klasyfikacja lessów oraz utworów lessopodobnych, Przeglad Geologiczny, vol. 48, no. 7, p. 580-586, 2000.

[19] Tutkowskyj P., K voprosu o sposobe obrazovaniy a lessa, Zemlevedeniye, vol. 6, no. 1-2, p. 213-311, 1899.

[20] Grahmann R., Der Löss in Europa. 1931.

[21] Pécsi M., Lösse und lössartige Sedimente im Karpatenbecken und ihre litostratigraphische Gliederung, Ptermanss Geographische Mitteilungen, vol. 110, p. 176-189; 241-252, 1966.

[22] Malinowski J., Badania geologiczno-inżynierskie lessów, 1971.

[23] Grabowska-Olszewska B., Osiadanie zapadowe lessów in: Przegląd Geologiczny, vol. 31, no. 3, p. $162-165,1983$.

[24] Stróżyk J., Charakterystyka ściśliwości gruntu pylastego, na przykładzie lessu z rejonu Wrocławia, Górnictwo i Geoinżynieria, vol. 1, p. 575-582, 2009.

[25] Nepelski K., Rudko M., Identyfikacja parametrów geotechnicznych lessów lubelskich na podstawie sondowań statycznych CPT, Przegląd Naukowy Inżynieria i Kształtowanie Środowiska, vol. 27, 
no. 2, p. 186-198, 2018.

[26] Nepelski K., Lal A., Franus M., Analiza wyznaczania konsystencji lessów lubelskich na podstawie wyników sondowań statycznych CPT, Budownictwo i Architektura, vol. 15, no. 4, p. 183-194, 2016, DOI:10.24358/Bud-Arch_16_154_18

[27] Charles Wang Wai Ng, Hamed Sadeghi, S.K. Belal Hossen, C.F. Chiu, Eduardo E. Alonso S. B., Water retention and volumetric characteristics of intact and re-compacted loess, Canadian Geotechnical Journal, vol. 53, no. 8, p. 1258-1269, 2016, https://doi.org/10.1139/cgj-2015-0364.

[28] Delage P., Cui Y. J., Antoine P., Geotechnical problems related with loess deposits in Northern France, Proceedings of International Conference on Problematic Soils, no. May, p. 517-540, 2005.

[29] Delage P., Geotechnical Problems Due To The Collapse Of Unsaturated Soils: The Case Of Loess From Northern France, Journal of Applied Engineering Science \& Technology, vol. 1, no. 1, p. 17-22, 2014.

[30] Cui Y.-J., Terpereau J.-M., Marcial D., Delage P., Antoine P., Marchadier G., Ye W.-M., A geological and geotechnical characterisation of the loess of Northern France, Skempton Memorial Conference, 2004, p. 417-428.

[31] Knight K., The origin and occurrence of collapsing soils, Reg. African CSMFE (1), 1963, p. $127-130$.

[32] Assallay A. M., Rogers C. D. F., Smalley I. J., Formation and collapse of metastable particle packings and open structures in loess deposits, Engineering Geology, vol. 48, no. 1-2, p. 101-115, 1997.

[33] Langroudi A. A., Micromechanics of collapse in loess, no. August, 2014.

[34] Langroudi A. A., Jefferson I., Collapsibility in calcareous clayey loess, International Journal of GEOMATE, vol. 5, no. 1, p. 620-627, 2013.

[35] Dobrescu C. F., Calarasu E. A., Ungureanu V. V, Engineering approach on stability assessment of loess soil structures considering basic geotechnical characteristics, Bulletin of the Transilvania University of Braşov, vol. 9, no. 58, 2016.

[36] Dušan B., Zoran B., Čebašek V., Šušić N., Characterisation of collapsing loess by seismic dilatometer, Engineering Geology, vol. 181, p. 180-189, 2014.

[37] Santrač P., Bajić Ž., Grković S., Kukaras D., Hegediš I., Analysis of calculated and observed settlements of the silo on loess, Tehnicki vjesnik - Technical Gazette, vol. 22, no. 2, p. 539-545, 2015.

[38] Zourmpakis A., Boardman D. I., Rogers C. D. F., Jefferson I., Gunn D. A., Jackson P. D., Northmore K. J., Entwisle D. C., Nelder L. M., Dixon N., Case study of a loess collapse field trial in Kent, SE England, Quarterly Journal of Engineering Geology and Hydrogeology, vol. 39, no. 2, p. 131-150, May, 2006.

[39] Mahler A., Turi D., Vonza C., Evaluation of the collapsibility risk of loess based on oedometer test results, no. 1963, p. 135-139, 2011.

[40] Jefferson I., Rogers C., Evstatiev D., Karastanev D., Treatment of metastable loess soils: Lessons from Eastern Europe, Elsevier Geo-Engineering Book Series, vol. 3, no. C. p. 723-762, 2005.

[41] Lutenegger A. J., Dynamic Compaction in Friable Loess, Journal of Geotechnical Engineering, vol. 112, no. 6. p. 663-667, 1986.

[42] Dumitru M., Geotechnical Testing for Certification of Loess Improvement By Dynamic Compaction, 5th International Young Geotechnical Engineers' Conference, 2013.

[43] Bally J. R., Some specific problems of wetted loessial soils in civil engineering, Engineering Geology, vol. 25, no. 2-4. p. 303-324, 1988.

[44] Evstatiev D., Loess improvement methods, Engineering Geology, vol. 25, no. 2, p. 341-366, 1988.

[45] Tabarsa A., Latifi N., Meehan C. L., Manahiloh K. N., Laboratory investigation and field 
evaluation of loess improvement using nanoclay - A sustainable material for construction, Construction and Building Materials, vol. 158, p. 454-463, 2018, https://doi.org/10.1016/j. conbuildmat.2017.09.096.

[46] Baranova M., Maltsev A., Vasilyeva D., Environmental construction safety on loess soils in the coastal zone of reservoirs, vol. 02015, 2017.

[47] Fodor P., Kleb B., Engineering geological problems in loess regions of hungary, Quaternary Intenational, vol. 24, no. C, p. 25-30, 1994.

[48] Olyansky Y. I., Kuzmenko I. Y., Shchekochikhina E. V., Features of Construction Buildings on the Loessial Soil of Central Moldova, Procedia Engineering, vol. 150, p. 2208-2212, 2016, https:// doi.org/10.1016/j.proeng.2016.07.265. 